\title{
THE USE OF POSITIVE LANGUAGE ON CHILDREN EDUCATION TO BUILD CHILDREN'S POSITIVE BEHAVIOUR
}

\author{
Amrina Rosyada; Ayu Bandu Retnomurti \\ Department of English Education, Faculty of Language and Art, University of Indraprasta PGRI \\ Jalan Nangka No. 58C Tanjung Barat, Jagakarsa, Jakarta Selatan 12530 \\ 4mrin4@gmail,com, ayubandu@gmail.com
}

\begin{abstract}
Language as the basic right of children is the most important thing to build their characters that required from their closest environment, family. Mother is the first person who will put and create the children's characters. The use of positive language by a mother will build on children's positive characters. Therefore, this research aims at determining the use of positive language by mothers in Majelis Taklim Baitul Hasan Jagakarsa, on children education to build their positive behavior. This research employing a cross-sectional survey method with attitudinal questionnaire of ten questions with the total respondents of 118 people. By implementing the formula of positive language, mothers will hopefully understand more the use of positive language on children education.
\end{abstract}

Key words: positive language, positive behavior, the formula of positive language

\begin{abstract}
ABSTRAK
Bahasa yang diperoleh seorang anak sebagai hak dasarnya adalah hal terpenting dalam membentuk kepribadiannya yang diperolehnya dari lingkungan yang terdekat yaitu keluarga. Ibu adalah orang pertama yang akan meletakkan dan membentuk kepribadian seorang anak. Penggunaan bahasa positif oleh seorang Ibu akan membangun kepribadian yang juga positif pada seorang anak. Oleh karena itu, penelitian ini bertujuan untuk mengetahui penggunaan bahasa positif oleh para Ibu di lingkungan Majelis Taklim Baitul Hasan Jagakarsa, dalam mendidik anak untuk membangun kebiasaan positif mereka. Penelitian ini menggunakan metode cross-sectional survey berupa kuesioner kebiasaan yang terdiri dari 10 (sepuluh) daftar pertanyaan dengan total responden sebanyak 118 orang. Dengan memberikan formula panduan bahasa positif, diharapkan para Ibu dapat lebih memahami penggunaan bahasa positif dalam mendidik anak.
\end{abstract}

Kata kunci: bahasa positif, kepribadian positif, formula panduan bahasa positif 


\section{INTRODUCTION}

Majelis taklim Baitul Hasan Jagakarsa is one of the learning centers for Moslem's community around Jagakarsa district where the religion activities are usually held by the community. This learning center was built independently by the community concerning to the community's needs of learning process from early childhood education through over-age people's education. All the learning activities are based on the Moslem's principles of Al Quran and Al Hadith in purity and sincerity, related to science development in human life. Like many other majelis taklim in all over Indonesia, this majelis taklim is authorized under the Dewan Kemakmuran Masjid (DKM).

As the learning center, majelis taklim Baitul Hasan has many daily programs. Besides the five times praying, this learning center also has supreme programs which are Halaqah Tahfidz Quran Ma'had Baitul Hasan for kids from elementary school to junior high school every twice a week; Cabe Rawit community for children from early years to elementary school every twice a week; Teens community for teenagers from junior high school to senior high school every twice a week; Women's community every once a week and women's day seminar once a month; martial art training for children of elementary school to senior high school every twice a week; and many other programs.

This research began with the observation on women's program in every once a week. Writers found that some of mothers in majelis taklim Baitul Hasan Jagakarsa didn't respond their children with proper responses. Most of them chose to respond their children by buying some snacks or candies when the children cried or got very noisy in the majelis taklim. They even violated their children's pride by getting mad at the children or even yelling at them. For mothers, to make the children stop their crying or their noisy was the most important thing, no matter how. Mothers seemed to give a short feedback and have a quick conversation to their children that the children felt being ignored. Unfortunately, with no realize mothers create a big picture on children's memory of their attitude and also their characters. Those conditions due to less knowledge of mothers about how important the use of language in building children's character. Mothers also have less motivation to read or to broaden their horizon on how to use positive language to their children. What is more, television and gadget at home are already replaced the mothers' role in building children's characters.

Based on the conditions, with the coordination to the DKM of majelis taklim Baitul Hasan, the writers provide a one-day seminar for mothers about the important role of mothers' language that affects their children's character building. This seminar is very important for mothers to open their new perspective on how language can create children's characters. Hopefully, mothers will be inspired and willingly apply the positive language to their children on their daily life.

According to Ball-Jessica (2011:13), "Language is not only a tool for communication and knowledge, but also a fundamental attribute of cultural identity and empowerment, both for the individual and the group." It shows the most important function of language for human life, how the language can reflect someone's character. Therefore, language education that required by the children as the basic right is the most important thing to build their characters. Children's character becomes the responsibility for their parent and family, 
a place where the education began. Mother is the first person who touches the children directly, and because of her can develop the children's character. The use of positive language by a mother will develop on children's positive character, as what Ball-Jessica (2011:13) stated as follows:

"Mother tongue instruction generally refers to the use of the learners' mother tongue as the medium of instruction. Additionally, it can refer to L1 as a subject of instruction. It is considered to be an important component of quality education, particularly in the early years. The expert view is that mother tongue instruction should cover both the teaching of and the teaching through this language."

There are also other aspects that effect a child's character in the future besides the use of the language. One of the most important aspect is parent's approach to their children. LexmondJohn \& Reeves-Richard (2009: 31) stated, "Parents' approach to their children-their level of warmth, responsiveness, control and disciplineare strongly influential on children's character capability development." Parents have to be aware on those aspects so that they can develop a quality approach on children's growth. Building a strong positive character of children is not a single education aspect, but it is about comprehensive and continuous education aspects that should be implemented on children's daily activities.

The use of positive language as one of the most important aspect has shown the effective results of positive behavior on children's character in many countries in Europe and America. One of the researcher, Sue R. J. Law et al.
(2010), have proved the success of using positive language on building children's character, especially for the early five years children in Bristol, British. She concluded that the use of positive language and the performance of positive environment have given a remarkable output on building the children's positive character. Based on that research, the writers have a strong belief to inspire mothers in majelis taklim Baitul Hasan about positive language and to encourage them in implementing the positive language in their daily life, aims at building their children characters.

\section{METHOD}

In this research, writers conducted the cross-sectional survey method in collecting the data. The data was collected at the time of event, which was on the day of the seminar. This method was conducted to find out and to measure mothers' attitude in using positive language on their children's education. A set of questionnaire was used as the research instrument, consist of ten questions with proportional answers and different scores. Writers also conducted groups' discussion method to encourage the participants' responses. The data calculated by scoring and summarizing all the responses in the questionnaires' form and in the discussion session. All data then being analyzed and performed in diagrams and table, and described in statistical description.

This research engaged 118 women participants who are housewives and live around the majelis taklim Baitul Hasan, Jagakarsa, South Jakarta. All participants joined the one day women's seminar and fulfilled all questions in the questionnaire. The participants also actively interacted through the seminar performance in the form of responses, questions, or advice. The participants 
even concluded their own summary of the seminar's presentation.

\section{RESULTS AND DISCUSSION}

Based on the scoring and summarizing the data of 118 participants, the result shows that 28.81 $\%$ participants or about 34 participants are at the high level in implementing positive language to their children; 69.49 $\%$ or about 82 participants are at the medium level in implementing positive language to their children; and the rest of $1.70 \%$ or about 2 participants are at the low level in implementing positive language to their children. See the following diagram for clear statistical description.

\section{The Use of Positive Language}

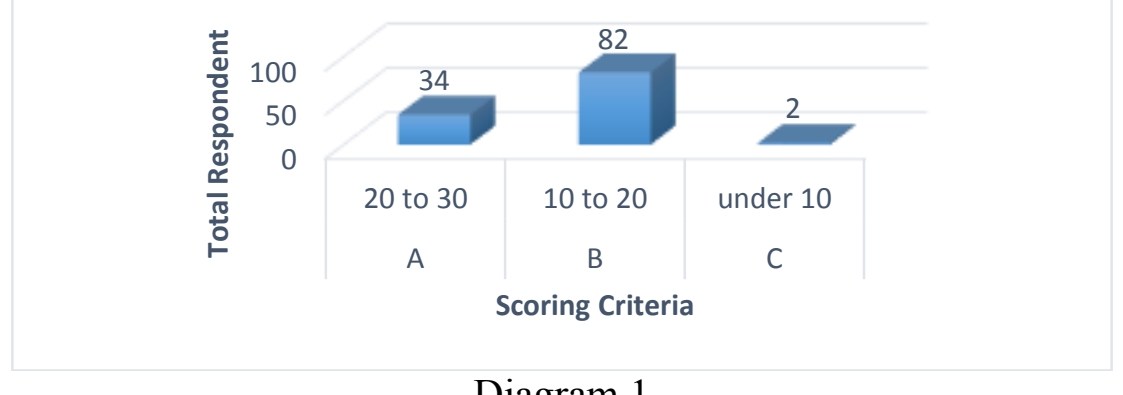

Diagram 1

The Use of Positive Language Result

The above diagram shows that 34 participants are at the high level in implementing positive language to their children with A categorized and scored 20-30; 82 participants are at the medium level in implementing positive language to their children with B categorized and scored 10-20; and the rest are 2 participants at the low level in implementing positive language to their children with $\mathrm{C}$ categorized and scored under 10. In the seminar, most of the participants performed enthusiastic and interactive responses that showed their willingness to have a new perspective of the use of positive language and avoid negative language on their children education.

Based on the questionnaire data, basically most mothers in majelis taklim Baitul Hasan have already known about the use of positive language in building their children's character. But in reality, mothers have many difficulties to implement the positive language because of some factors. A mother as a multitasking person, has so many responsibilities for her family, which are started from an early morning till late at night. Mostly, a mother feels exhausted because of her children matters, her household matters, her financial matters and many others. In this situation, mother usually ignores the use of positive language and use her casual language that actually impacts negative meaning on her children's mind. The worst is a mother gets confused and cannot differ the difference between the positive language and the negative one.

On the seminar, the writers encourage the audience about many issues of children education, especially on children's character building. There are some important issues that have been delivered to the audience, which are: (1) knowing children's behavior; different age different behavior; (3) belief, behavior and character; (4) positive language versus negative 
language; (5) positive language guidance; and (6) positive language behavior into positive character. All issues have been discussed and summarized by the audience interactively.

For the first issue, there are two important things that the children have to face: (1) learn about accepted behavior; and (2) manage their behavior. One thing to be noticed that positive behavior is very different to discipline. Discipline is about order and punishments are attached on it. For instance, when parent decided to schedule the dinner time at 7 p.m. but the children didn't come on time and then mother would clean up the table so that the children would not get the meal. That situation would be noticed by the children as the punishment for not coming on time at dinner time rather than a positive behavior. It would be very different if the parent wait for the children to come on the table and make a relax conversation while waiting for another family members. Children would notice that situation in positive mind to be an honor for them, as a member of the family and as a whole family.

The second issue is talking about identifying children's behavior based on their age. Indeed, it is different age different behavior and cause different language in use. It will be very different the reaction of two different age children of 2 years old boy and 7 years old boy when you give them a soccer ball. For the 7 years old boy, the ball will be kicked off and played in the backyard. What will happen with the ball on the 2 years old boy? For the 2 years old boy, the ball probably will be hugged, starred, or talked to.

Another issue is about belief, behavior, and character. As the Moslem's community, the audience have a strong belief that Islam with Al Qur'an and Al
Hadith are the main source of all science in this entire life, including the human life. They refer to Al Qur'an for Ali Imran: 159 and Al Hadith for Muslim about Islam's rules on children education. In Islam, parents are mostly responsible for their children. Every children was born in genuine character of honest and sincere. It is the parents who create the children's character to become a good person or a bad one in the future. Islam told the parents to treat and raise their children in positive language, positive mind, and positive attitude. The parents started it by giving the great names of their children.

Basically, the use of language can be categorized into two different meaning, which are positive language and negative language. Positive language is a language that effects a good image, warm and comfort feeling to the hearers. Meanwhile, the negative language is a language that effects a bad image and terrible feeling to the hearers, or even cause a conflict. Language as the communication tool is the effective system to express speaker's idea to the hearer. As Newson M. et.al. (2006:1) said as follows:

"Whatever else language might be (e.g. a method of communicating, something to aid thought, a form of entertainment or of aesthetic appreciation) it is first and foremost a system that enables people who speak it to produce and understand linguistic expressions."

According to Pranowo (2009), there are several characteristics of positive language, which are: (1) telling what to do; (2) giving solution; (3) impressing to help; and (4) focusing on positive action. On the other side, the negative language has several characteristics which are: (1) telling what's forbidden; (2) impressing to 
accuse; (3) using negative words such as: don't, never success, too late, what a lazy..., etc.; (4) focusing on negative action. Those characteristics are not easily applied by a mother, especially when a mother got very exhausted.

In the seminar, writers try to

Table 1

Positive Language Guidance deliver the form of positive language guidance to the audiences so that a mother can easily apply the positive language to their children at home. Based on Brogle-Brooke et.al. (2013) the guidance is as follows:

\begin{tabular}{|c|c|c|}
\hline No & $\begin{array}{l}\text { Positive } \\
\text { Language } \\
\text { Guidance }\end{array}$ & Descriptions \\
\hline 1. & $\begin{array}{l}\text { Replace } \\
\text { "Don't" } \\
\text { with "Do" }\end{array}$ & $\begin{array}{l}\text { Tell the children what they can do rather than tell the } \\
\text { children what they cannot do. For instance, when a kid } \\
\text { jumping on a sofa, rather than tell the kid not to jump } \\
\text { it'd better to tell the children, "Honey, it is a sofa. It is } \\
\text { very warm to sit over it. Come and sit with me honey." }\end{array}$ \\
\hline 2. & $\begin{array}{l}\text { Offer } \\
\text { Choice }\end{array}$ & $\begin{array}{l}\text { Give the children some choices to do that the children } \\
\text { feel there are so many things can be done. Parents will } \\
\text { control the choices but the children will feel that they } \\
\text { have so many opportunities to do what they want } \\
\text { without being controlled. }\end{array}$ \\
\hline 3. & $\begin{array}{l}\text { Tell Your } \\
\text { Child } \\
\text { "When" }\end{array}$ & $\begin{array}{l}\text { When the children ask the parents to do or to buy } \\
\text { something and parents disagree, it is better for parents } \\
\text { telling them to do it or to buy it in another time, rather } \\
\text { than telling them "No". Make sure that parents are able } \\
\text { to do it or to buy it in their settled time, so that the } \\
\text { children learn to keep a promise. }\end{array}$ \\
\hline 4. & $\begin{array}{l}\text { Use "First- } \\
\text { then"” } \\
\text { Language }\end{array}$ & $\begin{array}{l}\text { Another language that parents can ask to their children } \\
\text { is by telling them first-then language, not give an order. } \\
\text { For instance, when children come home from school, } \\
\text { put their shoes anywhere, and take some fruit without } \\
\text { washing their hands first, parents can tell them, "Sweet } \\
\text { heart, I think it's better for you to put your shoes at the } \\
\text { shoes' rack, wash your hands first, then take some fruit } \\
\text { for you." }\end{array}$ \\
\hline 5. & $\begin{array}{l}\text { Give Your } \\
\text { Child Time } \\
\text { to Think }\end{array}$ & $\begin{array}{l}\text { When parents ask the children to do something and the } \\
\text { children seem to be not responding, parents have to } \\
\text { wait and give the children time to think. Actually, } \\
\text { children need time to think to understand parents' } \\
\text { request before doing it. Different child will need } \\
\text { different time consuming. }\end{array}$ \\
\hline 6. & $\begin{array}{l}\text { Help Your } \\
\text { Child to }\end{array}$ & $\begin{array}{l}\text { Asking the children to do something, sometimes time } \\
\text { consuming or even being forgotten by the children. }\end{array}$ \\
\hline
\end{tabular}




\begin{tabular}{|l|l|} 
Remember & $\begin{array}{l}\text { Parents have to wait and remind the children what they } \\
\text { have to do. Parents can say, "Honey, I remember that } \\
\text { you have something to do". In this way, children learn } \\
\text { to remember things that they have to do without feeling } \\
\text { guilty or uncomfortable. }\end{array}$
\end{tabular}

Those six positive languages, hopefully can be a guidance for the parents especially mother. With the guidance, mother can easily apply the positive language to their children from day to day at home. With daily application, the positive language can create positive environment so then create positive behavior for the children. This positive behavior will develop the children's positive character.

Based on many researches on early childhood education in many countries, such as in United States (Harvard Family Research Project: 2006), Nigeria (Fagbeminiyi, F.: 2011), and Czech Republic (Taguma, M. et. al.: 2012), have concluded that it is very essential for children education by the role of family involvement. Besides the positive language, there are also some other aspects that have to be concerned in building the children's positive characters as Lexmond-John \& ReevesRichard (2009:31) stated, "Parents' approach to their children-their level of warmth, responsiveness, control and discipline- are strongly influential on children's character capability development."

Building the children's positive character is not a single aspect consideration, but it is about comprehensive and continuous aspects to be implemented on children's education. The word discipline on the above statement, means honorable to the children not a punishment. All the aspects would be affected when the parents and the children build their emotional bonding that grow up from day to day relation.

\section{CONCLUSION}

Based on the data of 118 participants, the result shows that 28.81 $\%$ participants or about 34 participants are at the high level in implementing positive language to their children; 69.49 $\%$ or about 82 participants are at the medium level in implementing positive language to their children; and the rest of $1.70 \%$ or about 2 participants are at the low level in implementing positive language to their children. It means that most of the mothers have implemented the positive language on their children education. Unfortunately, the implementation was not clearly defined as the positive language since mothers do not understand the difference between the positive and the negative language. Mothers also missed the process of the use of the positive language as the behavior language.

Therefore, the women's seminar has broaden mothers' perspective to be more aware and consciously apply the positive language to create positive environment for their children. This is in parallel to Al Qur'an and Al Hadith, specifically in Ali Imran: 159 that stated to soften parents' voice to the children. This verse means that parents are supposed to deliver their messages to their children in a soft and lovely words. Choosing the proper words with the soft and lovely words would be easily understood and even stored in children's mind and heart in long lasting period. Children will notice the parents' expression too as the figure of their life. As the communication function, language in oral or in written, with the expression of the speakers will affect the 
hearers' acceptance whether positively or negatively. Even when the hearers receive a bad news, the news will be considered positive in a way of positive deliverance. The use of positive language will be easily understood than the use of negative language or confrontation.

The positive language guidance to mothers in majelis taklim Baitul Hasan surroundings are distributed in the form of flyers. This guidance are combined with mothers' belief of Islam, aims at changing the perspective of mothers and their behavior on children's language education. It is very important to mothers to implement the guidance in accordance of children's building character, and it has to be started now. Positive perspective will create positive language, and when continuously applied as the positive behavior will create positive environment. This positive environment in each family will create an ideal positive environment in one area, to another area, or even to a district and another district. This ideal environment will build a better environment of the children, a better future of the next generation of a nation.

\section{REFERENCES}

Ball, J. (2011). Enhancing Learning of Children from Diverse Language Backgrounds: Mother Tongue-Based Bilingual or Multilingual Education in the Early Years. Paris, France: UNESCO.

Brogle, B. et.al. (2013). How to use positive language to improve your child's behavior. Technical assistance center on social emotional intervention from http://www.challenging behavior.org/ downloaded on October $12^{\text {th }}, 2015$.

Claire, K. (2009). Language and Culture. Oxford, New York: Oxford University Press.

Crain, W. (2007). Teori Perkembangan Konsep dan Aplikasi.Yogyakarta: Pustaka Pelajar.

Creswell, J.W. (2012). Educational Research; Planning, Conducting and Evaluating Quantitative and Qualitative Research. Boston: Pearson Education, Inc.

Fagbeminiyi, F. (2011). The role of parents in early childhood education: a case study of ikeja, lagos state, nigeria. Global Journal of Human Resources, 1(2), 78-96.

Law, J. et al. (2010). Investigating the role of language in children's early educational outcomes. Research Report on Department for Education, UK.

Lexmond, J. \& Reeves, R. (2009). Building Character: Parents are the Principal Architects of a Fairer Society. First Published. London, UK: DEMOS.

Newson, M., et.al. (2006). Basic English Syntax with Exercises. Bölcsész Konzorcium HEFOP Iroda.

Pranowo. (2009). Berbahasa Secara Santun. Yogyakarta: Pustaka Pelajar.

Taguma, M. et al. (2012). Quality Matters in Early Childhood Education and Care. OECD. Czech Republic.

Weiss, H. et al. (2008). Family Involvement in Early Childhood Education. Harvard Family Research Project No. 1 in A Series. USA. 